\title{
Air pollution and risk of hospitalization for epilepsy: the role of farm use of nitrogen fertilizers and emissions of the agricultural air pollutant, nitrous oxide
}

Poluição do ar e risco de hospitalização por epilepsia: o papel do uso agrícola de fertilizantes nitrogenados e as emissões de poluente atmosférico agrícola, óxido nitroso

Keith Fluegge ${ }^{1}$ Kyle Fluegge ${ }^{1,2}$

\begin{abstract}
The link between various air pollutants and hospitalization for epilepsy has come under scrutiny. We have proposed that exposure to air pollution and specifically the pervasive agricultural air pollutant and greenhouse gas, nitrous oxide $\left(\mathrm{N}_{2} \mathrm{O}\right)$, may provoke susceptibility to neurodevelopmental disorders. Evidence supports a role of $\mathrm{N}_{2} \mathrm{O}$ exposure in reducing epileptiform seizure activity, while withdrawal from the drug has been shown to induce seizure-like activity. Therefore, we show here that the statewide use of anthropogenic nitrogen fertilizers (the most recognized causal contributor to environmental $\mathrm{N}_{2} \mathrm{O}$ burden) is significantly negatively associated with hospitalization for epilepsy in all three pre-specified hospitalization categories, even after multiple pollutant comparison correction ( $p<.007$ ), while the other identified pollutants were not consistently statistically significantly associated with hospitalization for epilepsy. We discuss potential neurological mechanisms underpinning this association between air pollutants associated with farm use of anthropogenic nitrogen fertilizers and hospitalization for epilepsy.
\end{abstract}

Keywords: epilepsy; hospitalization; air pollution; fertilizers; nitrous oxide.

RESUMO

A ligação entre vários poluentes do ar e a hospitalização por epilepsia tem sido examinada. Propusemos que a exposição à poluição do ar, especificamente ao poluente atmosférico generalizado e ao gás de efeito estufa, o óxido nitroso ( $\mathrm{N}_{2} \mathrm{O}$ ), poderiam fomentar a susceptibilidade a distúrbios do desenvolvimento neurológico. A evidência apoia o papel da exposição ao $\mathrm{N}_{2} \mathrm{O}$ na redução da atividade convulsiva epileptiforme, enquanto mostra que a retirada do fármaco induz atividade pseudo-convulsiva. Portanto, mostramos aqui que o uso a nível estatal de fertilizantes nitrogenados antropogênicos (o agente causal mais reconhecido para a carga ambiental de $\mathrm{N}_{2} \mathrm{O}$ ) está significativa e negativamente associado à hospitalização por epilepsia nas três categorias de hospitalização pré-especificadas, mesmo após a correção de comparação de poluentes múltiplos ( $p<0,007$ ), enquanto os outros poluentes identificados não foram consistentemente associados de forma estatística com a hospitalização por epilepsia. Discutimos possíveis mecanismos neurológicos subjacentes a esta associação entre poluentes atmosféricos associados ao uso agrícola de fertilizantes nitrogenados antropogênicos, e hospitalização por epilepsia.

Palavras-chave: epilepsia; hospitalização; poluição do ar; fertilizantes; óxido nitroso.

The link between air pollution and epilepsy has come under recent scrutiny. Scorza et al. ${ }^{1}$ have proposed that urban air pollution may be a significant factor influencing human health and, particularly, sudden unexpected death in epilepsy. As part of their analysis, the authors suggested nutritional interventions that may ameliorate epilepsy risk, including intake of omega-3 fatty acids ${ }^{1}$. Empirical evidence in support of a link between air pollution and epilepsy has emerged in recent years. Cakmak et al. ${ }^{2}$ performed a daily time-series analysis of the association between gaseous and particulate matter air pollution and hospitalization for epilepsy in Chile. The authors reported pooled city estimates of relative risk for hospitalization for epilepsy associated with changes in concentrations of various pollutants including nitrogen dioxides $\left(\mathrm{NO}_{2}\right)$, carbon monoxide $(\mathrm{CO})$, sulfur dioxide $\left(\mathrm{SO}_{2}\right)$, ozone $\left.\left(\mathrm{O}_{3}\right)\right)$, and particulate matter (both $\mathrm{PM}_{10}$ ) and $\mathrm{PM}_{2.5}$ ). The confidence

${ }^{1}$ Institute of Health and Environmental Research, Cleveland Ohio 44118;

${ }^{2}$ New York City Department of Health and Mental Hygiene,New York USA 11101-4132.

Correspondence: Keith Fluegge; Institute of Health and Environmental Research, P.O. Box 18442, Cleveland, Ohio 44118; E-mail: keithfluegge@gmail.com Conflict of interest: There is no conflict of interest to declare.

Received 16 February 2016; Received in final form 18 May 2017; Accepted 07 June 2017. 
intervals for all the identified pollutants indicated that air pollution may be a risk factor for hospitalizations for epilepsy. A hospital-record based investigation on the role of urban air pollution in epilepsy attack in a Chinese population has shown similar result, with a possible protective effect of ozone exposure ${ }^{3}$. Animal studies indicate that ozone exposure may exert a protective effect against pentylenetetrazole-induced seizures through the restoration of cellular redox balance and regulation of the Al adenosine receptor ${ }^{4}$. These studies cumulatively provide evidence in support of the claims made by Scorza et al. ${ }^{1}$ for a role of air pollution in modulating the risk of hospitalization for epilepsy.

Moreover, the work by Cakmak et al. ${ }^{2}$ was cited in a recent review by Chilean health authorities and government officials conducting a workshop to better understand how the economic reclassification of the country has impacted environmental health with a goal of identifying important areas for future improvement ${ }^{5}$. One specific recommendation made by the expert panel was to incorporate aspects of climate change in the future study of the human health effects of air pollution. Consistent with these stated goals, we have recently proposed, through empirical investigation and review, that exposure to air pollution and specifically the pervasive air pollutant and greenhouse gas, nitrous oxide $\left(\mathrm{N}_{2} \mathrm{O}\right)$, may provoke susceptibility to neurodevelopmental disorders, like attention-deficit hyperactivity disorder (ADHD) and autism spectrum disorders (ASD) $)^{6,7,8,9}$. Epilepsy is a recognized comorbidity in both $\mathrm{ADHD}$ and $\mathrm{ASD}^{10,11,12}$. We have previously highlighted clinical case reports ${ }^{13}$, as well as several animal studies ${ }^{14,15,16}$, which indicated the role of $\mathrm{N}_{2} \mathrm{O}$ exposure in reducing epileptiform seizure activity ${ }^{17}$, while withdrawal from the drug has been shown to induce seizure-like activity ${ }^{14,15,16}$. Our novel environmental $\mathrm{N}_{2} \mathrm{O}$-mediated hypothesis of neurodevelopmental impairment is supported by recent evidence indicating $\mathrm{N}_{2} \mathrm{O}$ hotspots in central Chile, given the following statement from the work:

“...in our study area (off central Chile), they have $\Delta \mathrm{N}_{2} \mathrm{O}$ three times higher than the average monthly $\Delta \mathrm{N}_{2} \mathrm{O} \ldots$ the increased $\mathrm{N}_{2} \mathrm{O}$ production seemed to be caused by the addition of anthropogenic $\mathrm{NO}_{3}^{-}$associated with strong river runoff and a subsequent reduction to $\mathrm{N}_{2} \mathrm{O}$ (i.e., partial denitrification) $)^{18}$ "

However, the aforementioned analyses by Cakmak et al. ${ }^{2}$, Xu et al. ${ }^{3}$, and Mallok et al. ${ }^{4}$ do not address the air pollutant, $\mathrm{N}_{2} \mathrm{O}$, in the discovered association between air pollution and risk for epilepsy hospitalization. Consistent with the future goals identified by Chilean health and government officials ${ }^{5}$, we attempt to qualify the prior work by these research groups by performing regression analyses using a state-based total of farm use of anthropogenic nitrogen fertilizer, which is thought to be the major environmental contributor to $\mathrm{N}_{2} \mathrm{O}$ emissions ${ }^{18,19}$. While we attempt to document prior associations, by Cakmak et al. ${ }^{2}$ and others, between certain air pollution exposures and hospitalization for epilepsy for years 2001 to 2005, we also wish to test our hypothesis that increasing use of anthropogenic nitrogen-based fertilizers in agriculture (the most recognized causal environmental contributor to $\mathrm{N}_{2} \mathrm{O}$ emissions) may be significantly and negatively associated with hospitalization for epilepsy. We rationalize this hypothesis by emphasizing prior clinical reports and animal studies indicating a $\mathrm{N}_{2} \mathrm{O}$-induced suppression of epileptiform activity. Coupled with our prior conclusions, this hypothesis, if supported, may support the co-morbid link between epilepsy and other neurodevelopmental disorders by suggesting both are related to exposure to (i.e., $\mathrm{ADHD}$ and $\mathrm{ASD}$ ) or withdrawal from (i.e., epilepsy) environmental $\mathrm{N}_{2} \mathrm{O}^{6,7,8,9,17}$.

\section{METHODS}

For years 1997 to 2006, inclusive, we have gathered data on the state sum totals of farm use of nitrogen fertilizers (in kilograms) ${ }^{20}$, described in the authors' prior epidemiological studies $^{7,9}$. Although the United States Geological Survey of the U.S. Department of the Interior states that "no warranty expressed or implied is made by the U.S. Geological Survey as to the accuracy of the data," we believe the use of county data on a state aggregated level is consistent with the recommendations of the United States Geological Survey ${ }^{20,21}$. Moreover, other government agencies, like the Environmental Protection Agency, make similar disclaimers regarding data contained on their organization's website ${ }^{22}$, yet researchers continue to utilize the Environmental Protection Agency data on air quality emissions ${ }^{23}$.

To replicate the work by Cakmak et al. ${ }^{2}$, the authors averaged all locale state estimations of the annual air concentration of the pollutants between 2001 to 2005 ( $\mathrm{NOx}$ and $\mathrm{SO}_{2}$ ) [one hour] in ppb, $\mathrm{O}_{3}$ and $\mathrm{CO}$ [eight hour run average] in ppm; $\mathrm{PM}_{10}$ total $0-10 \mathrm{~mm}$ standard temperature and pressure [24-hour] and $\mathrm{PM}_{2.5} \mathrm{~mm}$ [local conditions, 24 hour] in micrograms/cubic meter), using air quality data from the Environmental Protection Agency ${ }^{24}$. Our dependent condition of interest is hospitalization for both all-listed and principal diagnoses of epilepsy, derived from data using the Healthcare Cost and Utilization Project (HCUPnet) ${ }^{25}$, as has been performed previously ${ }^{7,9}$.

We conducted a Poisson regression methodology including two-way fixed effects. Briefly, a random variable $\mathrm{Y}$ is said to have a Poisson distribution with parameter $m$ if it takes integer values $y=0,1,2, \ldots$ with probability

$$
\operatorname{Pr}\{Y=y\}=\frac{e^{-\mu} \mu^{y}}{y !}
$$

for $\mathrm{m}>0$. The mean and variance of this distribution can be shown to be $\mathrm{E}(\mathrm{Y})=\operatorname{var}(\mathrm{Y})=\mathrm{m}$. We have a sample of 
$n$ observations of discharges related to epilepsy, $y_{1}, \mathrm{y}_{2}, \ldots, y_{\mathrm{n}}$, which are treated as realizations of independent Poisson random variables, with $Y_{\mathrm{ij}}, P\left(m_{\mathrm{ij}}\right)$, where $i$ represents a state and $j$ an observation year. In order to test the robustness of hypothesized associations, we selected, a priori, several categories of epilepsy discharge diagnoses, including the clinical classification software category designations provided by HCUPnet (CCS 83: epilepsy, convulsions), using both the all-listed total and principal discharge diagnoses. The ICD9 codes that comprise this CCS category include 345.0, 345.00, 345.01, 345.1, 345.10, 345.11, 345.2, 345.3, 345.4, 345.40, 345.41, $345.5,345.50,345.51,345.6,345.60,345.61,345.7,345.70$, 345.71, 345.8, 345.80, 345.81, 345.9, 345.90, 345.91, 780.3, 780.31, 780.32, 780.33, 780.39. Additionally, we tested the independent ICD9 diagnostic code 345.xx for epilepsy (all-listed discharge diagnoses). We let the logarithm of the mean depend on a vector of time-varying explanatory variables, $x_{\mathrm{ij},}$ such that the log-linear model is the following: $\log \left(m_{\mathrm{ij}}\right)=x_{\mathrm{ij}}{ }^{\prime} b_{1}$. Exponentiating, we have a multiplicative model for the mean discharges: $m_{\mathrm{ij}}=\exp \left\{x_{\mathrm{ij}}{ }^{\prime} b_{1}\right\}$. In each case, the exponentiated regression coefficient $\exp \left\{b_{1 \mathrm{ijk}}\right\}$ yields an incidence rate ratio, which represents a multiplicative effect of the $k$ th predictor on the mean. Increasing $x_{\mathrm{k}}$ by one log-unit multiplies the mean by a factor $\exp \left\{b_{1 \mathrm{k}}\right\}$. All regression analyses and related diagnostics were performed using $R$ (packages ggplot2 and sandwich with robust standard errors), as we have described previously ${ }^{7,9}$.

Although we are unable to directly replicate the methodology of Cakmak et al. ${ }^{2}$, we believe the strength of our two-way fixed effects Poisson statistical approach lies in the fact that we have both accounted for individual state-level heterogeneity among a greater number of locations (30 selected HCUP states versus seven Chilean urban centers) and controlled for correlations across a longer time series (10 years versus five years in the case of farm use of nitrogen fertilizers), thus reducing the likelihood for omitted variable bias in the modeling. While not considered by Cakmak et al. ${ }^{2}$, this approach may be important, given the role that edaphology may play in the flux of environmental air contaminants ${ }^{26}$, as well as the evolving legislation, especially in the United Sates, surrounding the regulation of air pollution over many decades ${ }^{27}$.

\section{RESULTS}

The percent changes of the various air pollutants studied in this investigation are presented in Table 1 . All pollutants decreased in concentration level from 2001 to 2005, with carbon monoxide, nitrogen dioxide, and sulfur dioxide decreasing the most. Figure 1 shows the increase in the annual sum of farm use of nitrogen fertilizers for the selected HCUP available states between 1997 and 2006. Figure 2 presents the annual sum of hospitalization discharges associated with all three categories of epilepsy included in this brief report in the selected HCUP states.

Table 2 shows the results of our two-way fixed effects Poisson regression models. The data indicate that the air pollutants identified by Cakmak et al. ${ }^{2}$ were not statistically significantly associated with hospitalization for all-listed diagnoses of epilepsy during the same time period after multiple comparison correction for the seven pollutants studied for each hospitalization category $(0.05 / 7=p<0.007)$. Nitrogen dioxide concentration showed a slight protective effect against hospitalization for epilepsy (345.xx), particularly when the condition was the principal diagnosis, but the results did not retain statistical significance when adjusting for multiple pollutant

Table 1. Average (standard deviation) annual pollutant concentration across all reporting HCUP states, 2001-2005, with percent change.

\begin{tabular}{|c|c|c|c|c|c|c|}
\hline Year & Carbon monoxide (ppm) & Nitrogen dioxide (ppb) & Ozone (ppm) & $\mathrm{PM}_{10}\left(\mathrm{mg} / \mathrm{m}^{3}\right)$ & $\mathrm{PM}_{2}\left(\mathrm{mg} / \mathrm{m}^{3}\right)$ & Sulfur dioxide (ppb) \\
\hline \multirow{2}{*}{2001} & \multirow{2}{*}{$0.62(0.22)$} & 29.02 & 0.04630 & 23.74 & 11.89 & 11.80 \\
\hline & & $(7.84)$ & $(0.00561)$ & $(5.28)$ & (2.36) & (6.68) \\
\hline \multirow{2}{*}{2002} & \multirow{2}{*}{$0.63(0.21)$} & 27.19 & 0.04695 & 23.47 & 11.36 & 10.64 \\
\hline & & (7.66) & $(0.00497)$ & $(5.68)$ & $(2.17)$ & $(6.02)$ \\
\hline \multirow{2}{*}{2003} & \multirow{2}{*}{$0.60(0.18)$} & 25.79 & 0.04582 & 23.35 & 10.87 & 10.31 \\
\hline & & $(7.60)$ & $(0.00411)$ & $(4.81)$ & $(2.25)$ & $(5.86)$ \\
\hline \multirow{2}{*}{2004} & \multirow{2}{*}{$0.55(0.17)$} & 24.04 & 0.04293 & 22.00 & 10.75 & 9.72 \\
\hline & & (7.31) & $(0.00382)$ & $(4.50)$ & $(1.98)$ & (5.95) \\
\hline \multirow{2}{*}{2005} & \multirow{2}{*}{$0.51(0.16)$} & 24.74 & 0.04625 & 23.31 & 11.55 & 10.09 \\
\hline & & $(7.07)$ & $(0.00475)$ & $(4.93)$ & $(2.38)$ & $(5.50)$ \\
\hline$\%$ change & -17.74 & -14.75 & -0.11 & -1.81 & -2.86 & -14.49 \\
\hline
\end{tabular}

HCUP: Healthcare Cost and Utilization Project. 


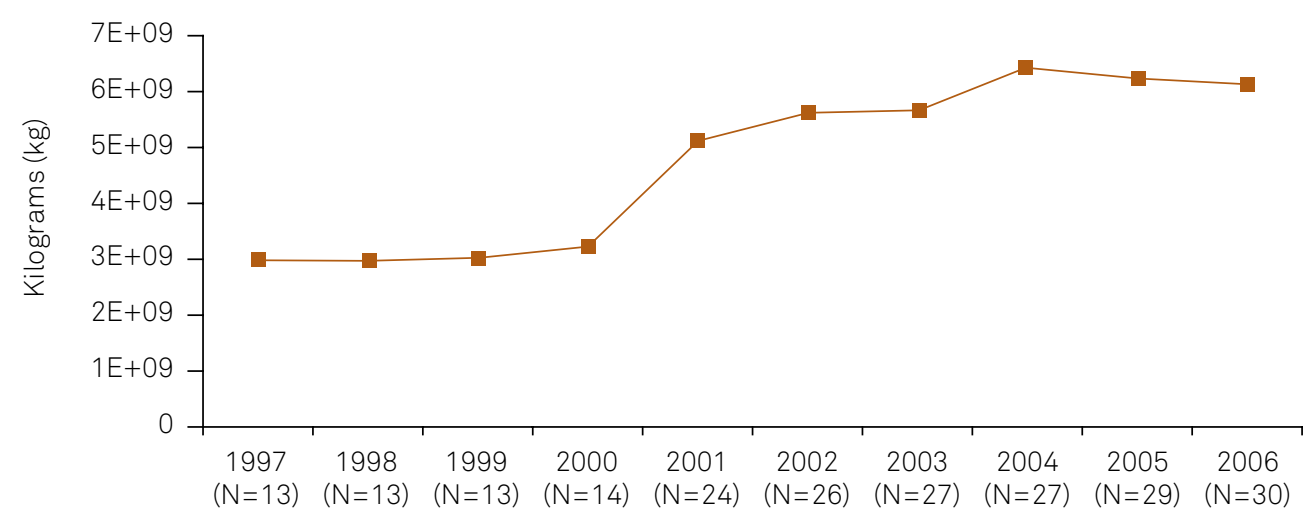

Year (Number of HCUP states)

HCUP: Healthcare Cost and Utilization Project

Figure 1. Annual sum of farm use of nitrogen fertilizers across all HCUP reporting states included in this analysis for all years available.

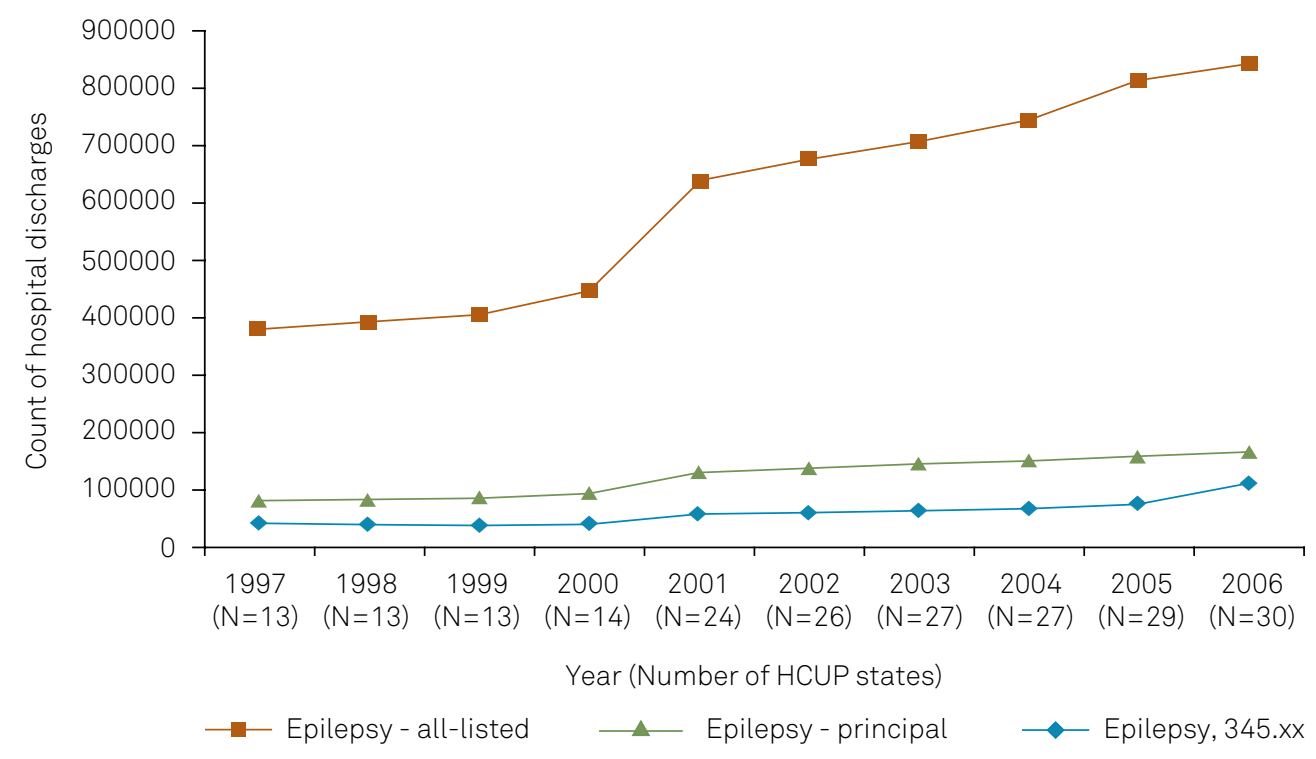

HCUP: Healthcare Cost and Utilization Project.

Figure 2. Annual sum of hospital discharge diagnoses across all HCUP reporting states included in this analysis for all years available. Categories include all-listed epilepsy discharges (Clinical Classification Software: 83), principal epilepsy discharges (Clinical Classification Software: 83), and all-listed epilepsy discharges using only ICD 9 classification code: 345.xx.

Table 2. Incident Rate Ratio of Hospitalization for Epilepsy Associated with a One Log-unit Change in Average Pollutant Concentrations using state and time fixed effects Poisson regression in R (packages ggplot2 and sandwich with robust standard errors) for all available HCUPnet states, United States, 2001-2005.

\begin{tabular}{|c|c|c|c|c|c|c|c|c|c|c|c|c|c|c|}
\hline \multirow{2}{*}{$\begin{array}{l}\text { Pollutant } \\
\text { (state-time } \\
\text { obs) }\end{array}$} & \multicolumn{2}{|c|}{$\begin{array}{l}\text { Carbon } \\
\text { monoxide } \\
(n=131)\end{array}$} & \multicolumn{2}{|c|}{$\begin{array}{l}\text { Ozone } \\
(n=131)\end{array}$} & \multicolumn{2}{|c|}{$\begin{array}{l}\text { Sulfur dioxide } \\
\qquad(\mathrm{n}=129)\end{array}$} & \multicolumn{2}{|c|}{$\begin{array}{l}\text { Nitrogen } \\
\text { Dioxide } \\
(n=124)\end{array}$} & \multicolumn{2}{|c|}{$\begin{array}{c}\mathrm{PM}_{10} \\
(\mathrm{n}=131)\end{array}$} & \multicolumn{2}{|c|}{$\begin{array}{c}\mathrm{PM}_{2.5} \\
(\mathrm{n}=128)\end{array}$} & \multicolumn{2}{|c|}{$\begin{array}{l}\text { Farm nitrogen }{ }^{a, b} \\
\qquad(n=216)\end{array}$} \\
\hline & IRR & $95 \% \mathrm{Cl}$ & IRR & $95 \% \mathrm{Cl}$ & IRR & $95 \% \mathrm{Cl}$ & IRR & $95 \% \mathrm{Cl}$ & IRR & $95 \% \mathrm{Cl}$ & IRR & $95 \% \mathrm{Cl}$ & IRR & $95 \% \mathrm{Cl}$ \\
\hline All-listed & 1.00 & $0.98-1.04$ & 0.91 & $0.83-1.00$ & 0.99 & $0.94-1.03$ & 1.02 & $0.97-1.08$ & 0.97 & $0.93-1.02$ & 0.96 & $0.87-1.06$ & 0.96 & $.93-.98 *$ \\
\hline Principal & 1.02 & $0.96-1.08$ & 0.91 & $0.78-1.07$ & 0.98 & $0.93-1.03$ & 0.93 & $\begin{array}{l}0.88 \\
0.98\end{array}$ & 0.99 & $0.92-1.06$ & 0.98 & $0.83-1.15$ & 0.92 & $.88-.96 *$ \\
\hline ICD9 (345.xx) & 1.09 & $0.98-1.21$ & 0.76 & $0.59-0.97$ & 0.99 & $0.91-1.08$ & 0.85 & $0.74-0.97$ & 0.95 & $0.85-1.07$ & 0.95 & $0.77-1.17$ & 0.82 & $0.74-0.90 *$ \\
\hline
\end{tabular}

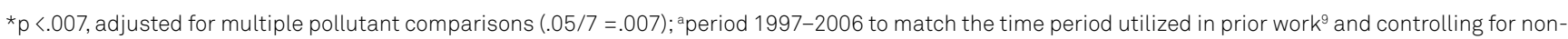
farm use of nitrogen fertilizers; ${ }^{\text {bas }}$ this variable acts as a proxy for air emissions of the agricultural pollutant, nitrous oxide $\left(\mathrm{N}_{2} \mathrm{O}\right)$, which depend upon the total nitrogen applied, sum state totals were used and log transformed.

HCUP: Healthcare Cost and Utilization Project. 
comparisons. However, a one-unit log increase in total annual farm use of nitrogen-based fertilizers in each state is significantly negatively associated with hospitalization for all three epilepsy categories studied. Further quartile analysis revealed that states above the $50^{\text {th }}$ percentile of farm use of nitrogen fertilizer (i.e., heavy agricultural states) saw the greatest protective effect against hospitalization for epilepsy. States below this percentile had no protective effect (data not shown).

\section{DISCUSSION}

The results of this brief report suggest a possible link between agricultural air pollution, particularly the farm use of anthropogenic nitrogen fertilizers and associated emissions of $\mathrm{N}_{2} \mathrm{O}$, and hospitalization for epilepsy in 30 states included in the HCUP database. However, this finding is reliant on the assumption that farm use of anthropogenic nitrogen fertilizers represents an accurate estimation of environmental $\mathrm{N}_{2} \mathrm{O}$ emissions. Although others have acknowledged this relationship ${ }^{19}$, we must exert some hesitation with the underlying interpretation of our results. For example, the potential for bias in our results cannot be discounted, as the finding that the protective effect of farm use of nitrogen fertilizers against hospitalization for epilepsy may be associated with a more rural lifestyle that is less afflicted by stress, a recognized trigger for epilepsy ${ }^{28}$. However, this explanation is not consistent with our prior work showing a disproportionate burden in hospitalization for other mental health comorbidities, like ADHD (1997-2006), that occurs in these less populated areas, as we have discussed ${ }^{7,9}$. A more consistent explanation that our collective studies now afford is that exposure to environmental anthropogenic nitrogen fertilizers used in agriculture and associated emissions of $\mathrm{N}_{2} \mathrm{O}$ may facilitate a continuum of psychiatric impairments; that is, increasing use of anthropogenic nitrogen fertilizers in agriculture and exposure to $\mathrm{N}_{2} \mathrm{O}$ leads to ADHD symptoms (i.e., working memory impairments and inattention), and withdrawal and/or tolerance facilitates epileptiform activity. Molecular evidence of $\mathrm{N}_{2} \mathrm{O}$ toxicity indicates an antagonism of $\mathrm{N}$-methyl-D-aspartate receptors, which may undergo a rapid upregulation in response to $\mathrm{N}_{2} \mathrm{O}$ withdrawal and/or tolerance, resulting in receptor hyperactivation and possible seizure generation ${ }^{29}$, as has previously been cited and discussed ${ }^{6,17}$.

We have attempted to replicate prior associations among other commonly studied air pollutants, like $\mathrm{CO}, \mathrm{O}_{3}$, NOx, SOx, and particulate matter but were not able to find consistent, statistically significant associations across the pre-specified hospitalization categories during the same time period studied by Cakmak et al. ${ }^{2}$. Additional analyses including a longer time series (1997-2006) were not able to alter these conclusions. These results suggest that future investigations seeking to elucidate the role of air pollution in risk of hospitalization for epilepsy should be expanded to include environmental emissions of the agricultural and combustion pollutant, $\mathrm{N}_{2} \mathrm{O}$, especially given the clinical evidence and preclinical animal studies directly associating $\mathrm{N}_{2} \mathrm{O}$ exposure with epileptiform activity ${ }^{13,14,15,16}$. While a protective effect of ozone did not meet our statistical significance after multiple pollutant comparison correction, epidemiological evidence indicating a potential protective effect of ozone in epilepsy should also consider that the effect may have to do with the possible role of $\mathrm{N}_{2} \mathrm{O}$ as an agent of ozone depletion ${ }^{30}$, in addition to any independent cellular mechanisms possibly at play ${ }^{4}$. Similarly, while nitrogen amended soils may leach $\mathrm{N}_{2} \mathrm{O}$ emissions, nitrogen dioxide fluxes may be minimized under conditions of agricultural fertilization ${ }^{31}$.

The current finding merges critical concepts of climate change into the growing burden of chronic human neurological illness and, in particular, suggests an important direction to take in the study of epilepsy and related comorbidity. Recent reports are indicating that current Intergovernmental Panel on Climate Change guidelines are underreporting indirect emissions of $\mathrm{N}_{2} \mathrm{O}$ by a magnitude from three- to nine-fold ${ }^{32,33}$, while Intergovernmental Panel on Climate Change methodologies presuming linear increases in direct soil $\mathrm{N}_{2} \mathrm{O}$ emissions as a function of nitrogen inputs may be missing true exponential rises in global emissions, especially under conditions of heavy fertilizer use (i.e., agriculture) ${ }^{19}$. Our data may be particularly revealing in this regard, considering that the greatest protective effect against hospitalization for epilepsy occurs in states that report the greatest amount of nitrogen fertilizers used in agriculture.

It is also interesting to further speculate on the association between environmental sources of $\mathrm{N}_{2} \mathrm{O}$ and risk of hospitalization for epilepsy by recognizing that diurnal variation in $\mathrm{N}_{2} \mathrm{O}$ flux ${ }^{34}$ (i.e., greater in the afternoon hours) may be negatively related to the early morning risk of seizure in generalized epilepsy ${ }^{35}$. Though, more research is needed to understand what role, if any, environmental exposure to $\mathrm{N}_{2} \mathrm{O}$ may have in human health assessments. While our presumption that the anthropogenic use of nitrogen fertilizers is directly reflective of environmental $\mathrm{N}_{2} \mathrm{O}$ burden is a limitation of the analysis, it remains our suggestion that scientists may need to reconfigure their thinking about particular environmental pollutants, like $\mathrm{N}_{2} \mathrm{O}$, recognizing that agents long thought to carry little-to-no harm in the controlled and acute medical setting may not exist in the daily environment in a similar manner.

\section{Acknowledgements}

The authors dedicate this work to Maddie Fluegge. 
1. Scorza CA, Calderazzo L, Arida RM, Cavalheiro EA, Scorza FA. Environmental air pollution is an aggravating event for sudden unexpected death in epilepsy. Arq Neuropsiquiatr. 2013;71(10):807-10. https://doi.org/10.1590/0004-282X20130092

2. Cakmak S, Dales RE, Vidal CB. Air pollution and hospitalization for epilepsy in Chile. Environ Int. 2010;36(6):501-5. https://doi.org/10.1016/j.envint.2010.03.008

3. Xu C, Fan YN, Kan HD, Chen RJ, Liu JH, Li YF et al. The novel relationship between urban air pollution and epilepsy: a time series study. PLoS One. 2016;11(8):e0161992. https://doi.org/10.1371/journal.pone.0161992

4. Mallok A, Vaillant JD, Soto MT, Viebahn-Hänsler R, Viart ML, Pérez AF et al. Ozone protective effects against PTZ-induced generalized seizures are mediated by reestablishment of cellular redox balance and $\mathrm{A} 1$ adenosine receptors. Neurol Res. 2015;37(3):204-10. https://doi.org/10.1179/1743132814Y.0000000445

5. Pino P, Iglesias V, Garreaud R, Cortés S, Canals M, Folch W et al. Chile confronts its environmental health future after 25 years of accelerated growth. Ann Glob Health. 2015;81(3):354-67. https://doi.org/10.1016/j.aogh.2015.06.008

6. Fluegge K. Does environmental exposure to the greenhouse gas, $\mathrm{N} 2 \mathrm{O}$, contribute to etiological factors in neurodevelopmental disorders? A mini-review of the evidence. Environ Toxicol Pharmacol. 2016;47:6-18. https://doi.org/10.1016/j.etap.2016.08.013

7. Fluegge K, Fluegge K. Glyphosate use predicts healthcare utilization for ADHD in the Healthcare Cost and Utilization Project net (HCUPnet): a two-way fixed-effects analysis. Pol J Environ Stud. 2016;25(4):1489-503. https://doi.org/10.15244/pjoes/61742

8. Fluegge K. Polycyclic aromatic hydrocarbons and child mental health: is the effect modified by exposure to environmental nitrous oxide? Environ Sci Pollut Res Int. 2016;23(23):24416-7. https://doi.org/10.1007/s11356-016-7837-0

9. Fluegge K, Fluegge K. Exposure to ambient PM10 and nitrogen dioxide and ADHD risk: a reply to Min \& Min (2017). Environ Int. 2017;103:109-10. https://doi.org/10.1016/j.envint.2017.02.012

10. Bertelsen EN, Larsen JT, Petersen L, Christensen J, Dalsgaard S. Childhood Epilepsy, Febrile Seizures, and Subsequent Risk of ADHD. Pediatrics. 2016;138(2):138. https://doi.org/10.1542/peds.2015-4654

11. Sundelin HE, Larsson H, Lichtenstein P, Almqvist C, Hultman CM, Tomson T Autism and epilepsy: A population-based nationwide cohort study. Neurology. 2016;87(2):192-7. https://doi.org/10.1212/WNL.0000000000002836

12. Williams AE, Giust JM, Kronenberger WG, Dunn DW. Epilepsy and attention-deficit hyperactivity disorder: links, risks, and challenges. Neuropsychiatr Dis Treat. 2016;12:287-96. Https://doi.org/10.2147/NDT.S81549

13. Artru AA, Lettich E, Colley PS, Ojemann GA. Nitrous oxide: suppression of focal epileptiform activity during inhalation, and spreading of seizure activity following withdrawal.J Neurosurg Anesthesiol.1990;2(3):189-93. https://doi.org/10.1097/00008506-199009000-00006

14. Belknap JK, Laursen SE, Crabbe JC. Ethanol and nitrous oxide produce withdrawal-induced convulsions by similar mechanisms in mice. Life Sci. 1987;41(17):2033-40. https://doi.org/10.1016/0024-3205(87)90477-2

15. Harper MH, Winter PM, Johnson BH, Koblin DD, Eger El II. Withdrawal convulsions in mice following nitrous oxide. Anesth Analg. 1980;59(1):19-21. https://doi.org/10.1213/00000539-198001000-00004

16. Smith RA, Winter PM, Smith M, Eger El II. Convulsions in mice after anesthesia. Anesthesiology. 1979;50(6):501-4. https://doi.org/10.1097/00000542-197906000-00005

17. Fluegge K. Does the association between ADHD and pediatric epilepsy signal a tolerance continuum to human environmental exposures? A reply to Salpekar and Mishra (2014). Epilepsy Behav. 2016;58:143-4. https://doi.org/10.1016/j.yebeh.2016.02.009

18. Farías L, Besoain V, García-Loyola S. Presence of nitrous oxide hotspots in the coastal upwelling area off central Chile: an analysis of temporal variability based on ten years of a biogeochemical time series. Environ Res Lett. 2015;10(4):044017. https://doi.org/10.1088/1748-9326/10/4/044017

19. Shcherbak I, Millar N, Robertson GP. Global metaanalysis of the nonlinear response of soil nitrous oxide (N2O) emissions to fertilizer nitrogen. Proc Natl Acad Sci USA. 2014;111(25):9199-204. https://doi.org/10.1073/pnas.1322434111

20. Gronberg JM, Spahr NE. County-level estimates of nitrogen and phosphorus from commercial fertilizer for the Conterminous United States, 1987-2006. U US Geol Surv Sci Investig Rep. 2012;5207:20.

21. Thelin GP, Stone WW. Estimation of annual agricultural pesticide use for counties of the conterminous United States, 1992-2009. US Geol Surv Sci Investig Rep. 2013;5009:54.

22. Environmental Protection Agency. EPA disclaimers. Washington, DC: Environmental Protection Agency ; 2016 [cited 2017 Jan]. Available from: http://www.epa.gov/home/epa-disclaimers

23. Baxter LK, Crooks JL, Sacks JD. Influence of exposure differences on cityto-city heterogeneity in PM2.5-mortality associations in US cities .Environ Health. 2017;16(1):1. https://doi.org/10.1186/s12940-016-0208-y

24. Environmental Protection Agency. Daily summary data: criteria gases. Washington, DC: Environmental Protection Agency; 2014 [cited 2014 Oct]. Available from: https://aqsdr1.epa.gov/aqsweb/ aqstmp/airdata/download_files.html

25. U.S. Department of Health and Human Services. Agency for Healthcare Research and Quality. Healthcare Cost and Utilization Project (HCUPNET): state inpatient database. Rockville, Md: Agency for Healthcare Research and Quality; 2014 [cited 2014 Oct]. Available from: http://hcupnet.ahrq.gov/

26. Smith WH. Air pollution and forests: interaction between air contaminants and forest ecosystems. Springer; 1981. Forests as sinks for air contaminants: soil compartment; p. 56-83. (Springer Series on Environmental Management).

27. Krupnick A, Morgenstern R. The future of benefit-cost analyses of the Clean Air Act. Annu Rev Public Health. 2002;23(1):427-48. https://doi.org/10.1146/annurev.publhealth.23.100901.140516

28. McKee HR, Privitera MD. Stress as a seizure precipitant: Identification, associated factors, and treatment options. Seizure. 2017;44:21-6. https://doi.org/10.1016/j.seizure.2016.12.009

29. Huberfeld G, Menendez de la Prida L, Pallud J, Cohen I, Le Van Quyen M, Adam C et al. Glutamatergic pre-ictal discharges emerge at the transition to seizure in human epilepsy. Nat Neurosci. 2011;14(5):627-34. https://doi.org/10.1038/nn.2790

30. Ravishankara AR, Daniel JS, Portmann RW. Nitrous oxide (N2O): the dominant ozone-depleting substance emitted in the 21st century. Science. 2009;326(5949):123-5. https://doi.org/10.1126/science.1176985

31. Akiyama $\mathrm{H}$, Tsuruta H. Nitrous oxide, nitric oxide, and nitrogen dioxide fluxes from soils after manure and urea application. J Environ Qual. 2003;32(2):423-31. https://doi.org/10.2134/jeq2003.4230

32. Beaulieu JJ, Tank JL, Hamilton SK, Wollheim WM, Hall RO Jr, Mulholland PJ et al. Nitrous oxide emission from denitrification in stream and river networks. Proc Natl Acad Sci USA. 2011;108(1):214-9. https://doi.org/10.1073/pnas.1011464108

33. Turner PA, Griffis TJ, Lee X, Baker JM, Venterea RT, Wood JD. Indirect nitrous oxide emissions from streams within the US Corn Belt scale with stream order. Proc Natl Acad Sci USA. 2015;112(32):9839-43. https://doi.org/10.1073/pnas.1503598112

34. Xu J, Wei Q, Yang S, Wang Y, Lv Y. Diurnal pattern of nitrous oxide emissions from soils under different vertical moisture distribution conditions. Chil J Agric Res. 2016;76(1):84-92. https://doi.org/10.4067/S0718-58392016000100012

35. Badawy RA, Macdonell RA, Jackson GD, Berkovic SF. Why do seizures in generalized epilepsy often occur in the morning? Neurology. 2009;73(3):218-22. https://doi.org/10.1212/WNL.0b013e3181ae7ca6 